\title{
Design of fire control system for LNG reception station in Binzhou port
}

\author{
Baocheng Lu ${ }^{1, a, *}$, Xiujun Nie ${ }^{1, b}$,Zhaoqiang Li ${ }^{1, c}$, Haijun Yang' and Qingyun Sun ${ }^{1}$ \\ ${ }^{1}$ Binzhou Polytechnic, Binzhou 256600, China \\ a 176816963@qq.com, b343637505@qq.com, creaderlzq@163.com
}

Keywords: LNG reception station; Fire; Fire fighting system; Design

\begin{abstract}
LNG berth is one of the key construction projects in Binzhou port. Its fire control design is the main part of the construction. According to the risk and characteristics of LNG, the design is designed according to the domestic relevant laws and regulations, and the plan and design scheme of the fire control system is put forward so as to meet the acceptance requirements and play the main role of the fire fighting system in the future.
\end{abstract}

\section{Introduction}

The LNG reception station is mainly composed of the unloading arm, the storage tank and other equipment. His function is to store the LNG transported from the ship to the LNG storage tank through a certain process. LNG is natural, pollution-free, safe, high quality, easy to store, transport and use. It has been widely applied. Because LNG has the characteristics of flammable, explosive, low temperature, easy to flow, fire and easy to diffuse. Once the fire spread fast, the influence is big, it is difficult to fight, the flame temperature is high, the heat radiation ability is strong, so we need to set up the corresponding fire protection facilities.

\section{Design basis}

Binzhou port LNG reception station, wharf and other projects are still in the planning stage, prepared in advance according to the plan and design of fire protection design plan, ahead of schedule, according to China's "code for fire and natural gas engineering design", "petrochemical enterprise design fire protection code", international "LNG preparation and installation", "LNG production and storage and transportation". According to the standard of transmission and other regulations, and referring to and drawing on the experience of the fire control design of the LNG reception station built in the Shandong port and other parts of the country, the specific plan and design of the fire control system are put forward.

\section{Analysis of fire hazard}

The fire hazard of LNG reception station mainly comes from LNG leakage and light fire heavy explosion. It mainly includes the following aspects: easy occurrence of LNG leakage, gas fire and even explosion of leaked gas, heat absorption of leakage gas and freezing injury on site workers, and electrical equipment fire in LNG reception station.

\section{Design of fire control system}

Fire planning and design can be divided into three parts: control system, detection system, alarm and fire extinguishing system.The composition of the fire control system is shown in Figure 1

\subsection{Control system}

The fire control station is the fire control center of the LNG reception station, which is divided into three parts: information analysis unit, fire control unit and information display unit. 


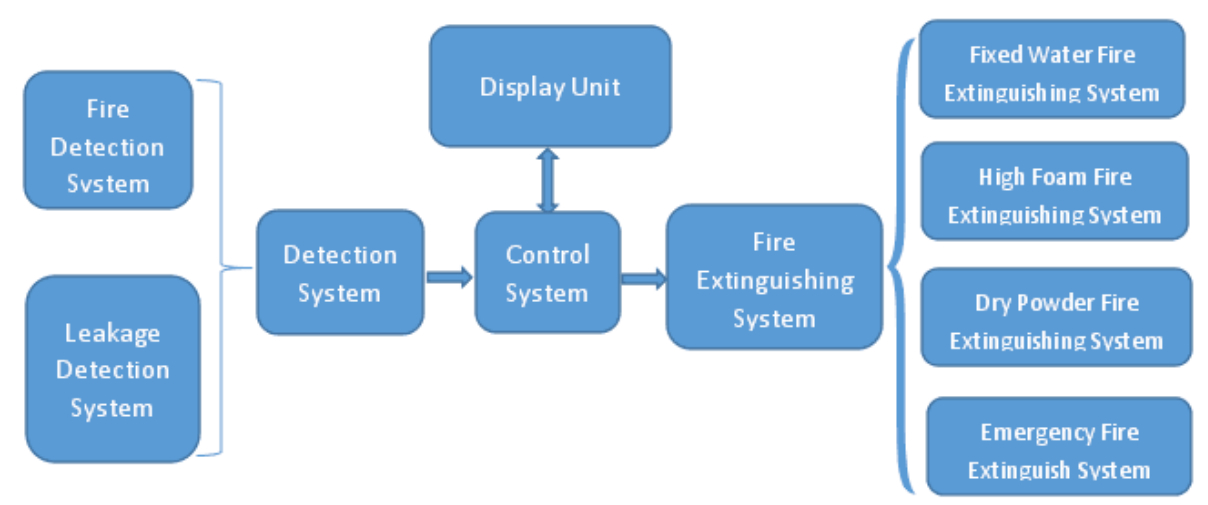

Fig1. LNG reception station fire system composition diagram

\subsubsection{Information analysis unit}

Information analysis unit is mainly based on detector monitoring and signal analysis, to determine whether there is fire or leakage. At the same time, it can detect the running state of the detector, judge whether it is normal, and patrol regularly, if the fault or abnormal item control system sends the signal, it usually has the self inspection function.

\subsubsection{Fire control unit}

Fire control unit is mainly based on the result of information analysis, sending out alarm and corresponding actions, realizing manual, automatic and test control mode. Fire control fire control design is the core, and the actual control of dry powder fire extinguishing system, high foam fire extinguishing system, fixed water fire extinguishing system, water curtain isolation system start, run and stop.

\subsubsection{The information unit}

The information display unit can view the equipment layout of the fire system of the LNG reception station, the fire protection parameters of the LNG reception station and the related operation information. It can be displayed on the device, and it can be realized by the touch screen. It can not only realize the real-time display of information, but also realize the sharing of information.

\subsection{Detection system}

The detection system can detect LNG leakage, gas fire and electric fire house.

\subsubsection{Leak detection}

Leak detection can install flammable gas detectors, flammable gas detectors and cryogenic detectors, and send signals to the controller. The flammable gas detector selects the RTTPP brand, the model DR-600, IP65, the output signal 4-20mA. The flammable gas alarm is selected by the brand of Bao Shi an, model 60EX. The cryogenic detector is Tae Hoon brand, model JTY-GFTX6190.

\subsubsection{Gas fire detection}

Gas fire detection is installed in the area of the detection of fire sensor, smoke detector and photosensitive detector, each detector has its own address code, representing their own area. The sensor selects the Bay brand, the model temperature sense JTW-ZCD-G3N, the smoke detector selects the Bay brand, the model GSTN701, the photosensitive detector chooses the Bay brand, the model GST9711Ex.

\subsubsection{The electric fire detection}

The electric fire detection is connected with the electric fire monitoring detector, the temperature sensing fire detector and the electromagnetic coil. The detector realizes the real-time monitoring of 
the change of the electrical equipment parameters, and transfers the electrical information to the control equipment, and the control equipment is analyzed and judged. The electric fire detector selects the people electric appliance brand, the model NA300A4.

\subsection{Fire extinguishing system}

In addition to the comprehensive consideration of the fire risk of the LNG reception station, it is necessary to establish a fire extinguishing system, a high foam fire extinguishing system, a fixed water fire extinguishing system, a water curtain isolation system and an emergency fire extinguishing equipment in addition to the fire prevention design in the overall port planning.

\subsubsection{The dry powder extinguishing system}

The dry powder extinguishing system is generally set up at the top of the LNG tank top release valve and the terminal, and a total of 1 sets are set up. Dry powder system consists of dry powder tank, nitrogen gas cylinder group, dry powder gun, dry powder hose reel, sprinkler and pipe network and corresponding control valves and instruments. The dry powder fire extinguishing system includes three control methods: automatic control, remote manual control and in-situ control, which requires at least 60 seconds of dry powder injection.

\subsubsection{High fold foam fire extinguishing system}

Generally, high multiple foam extinguishing system is usually installed in LNG terminal collection pool of LNG terminal, tank farm, process area and loading area. The main purpose is to suppress the spread of liquefied natural gas in the LNG collection pool. Generally, it consists of detection device, foam generator, proportional mixing method and controller. In order to ensure safety, we need to set up a fire dike. The high double foam fire extinguishing system is usually composed of 3\% high multiple foam liquid. The supply strength of the device is not less than $7.2 \mathrm{~L} /$ (min. M2), and the continuous supply time is less than $40 \mathrm{~min}$. The high multiple foam fire extinguishing system is controlled by two ways of automatic control and manual control. When the detector detects the fire signal, it first sends out the sound and light alarm to start the high multiple foam fire extinguishing system, and spray the foam into the collection pool, cool and cover the leaked LNG, and play the role of heat insulation.

\subsubsection{Fixed water fire extinguishing system}

In the whole reception station, a set of high pressure water proof system and a set of low pressure water proof system should be set up to make up a fixed water fire extinguishing system. The water proof system consists of fire water, fire water pump, fire water pipe network and fire proof water cannon. The high pressure water proof water system is kept under the pressure of fresh water from the pressure pump at $0.8 \mathrm{MPa}$, when the fire pump is started when the fire is in fire, the pressure is kept at 1.2 or $1.6 \mathrm{MPa}$, and the sea water is transferred when the fire extinguishing. The lowpressure firewater system mainly used fresh water, generally required to maintain pressure $0.8 \mathrm{MPa}$. In order to ensure safety and efficiency, the reception station uses double line water supply of fire pump and double line power supply. In accordance with the design, there are 3 fire pumps, of which 2 motors are driven, 1 diesel engines are driven, and 2 stations are used for 1 standby.

\subsubsection{Water curtain isolation system}

The water curtain isolation system is located between the unloading arm and the ship, which is located below the nozzle. The main function is to block the fireworks and the cooling isolation during the leakage, and the water spray strength should not be less than $2 \mathrm{~L} / \mathrm{s} \mathrm{m}$ according to the regulation. The principle of the work is to use the water from the fixed water fire extinguishing system to form a water curtain through a sprinkler to prevent the spread of fire and smoke, and to ensure that the leakage of LNG can not be left directly to the sea, but the effect of full dilution. The water curtain isolation system can be set up as an automatic control mode, and has functions of machine side and remote manual and emergency operation. After the fire occurred, when the probe detected the fire signal, the transmission current signal to the control system, first the alarm, and 
then the valve into the high pressure water to form the water curtain, thus forming a water curtain isolation system.

\subsubsection{Emergency fire extinguishing system}

Emergency fire extinguishing system includes portable fire extinguisher, emergency power supply, emergency fire pump and fire truck. In the LNG wharf, the tank area, the transportation vehicle loading area, the craft area and the buildings, the boat type fire extinguishers such as dry powder, carbon dioxide and other portable and foam should be equipped in accordance with the rules and regulations, and a fireproof map is placed in a significant position in order to extinguish the initial or small fires. In order to ensure continuous power supply, the terminal also needs to set up emergency power supply to ensure that there is electricity at all times. Emergency fire pump needs to move conveniently, and the amount of drainage is not lower than the hour. In order to ensure that the main fire fighting equipment is damaged or malfunction, the fire engine can be sent out, and fire passages are set up in the area of the code LNG irrigation area to ensure that the fire truck arrives without obstacle.

\section{Conclusion}

In recent years, the construction and development of the LNG reception station is very rapid. The technology of transportation and storage and loading and unloading is very mature, but at present there is no fire design standard for the LNG reception station which is specially formulated and perfected. The companies are still building the fire design of the LNG reception station according to the existing laws and regulations and standards in China, and carried out through the audit. . Because of the different construction scale and different sea area conditions of the LNG reception station, the fire equipment, the fire protection facilities and the fire equipment and site in the reception station are different in the design and planning. The design and planners should design and demonstrate according to the different terrain and sea area of the reception station according to the specific conditions and design a more safe and efficient fire control system. At the same time, the opinions and suggestions of the fire department, construction company and industry experts should be absorbed in the process of design and demonstration so as to ensure the design. The system can meet the requirements of laws and regulations, and is safe, high quality and efficient.

\section{Acknowledgements}

Research and development of adiabatic technology for LNG reception station in Binzhou port.

\section{References}

[1]Zhang Weifang, LNG,the fire protection design plan of the fully frozen storage tank area, [J].industrial water and wastewater.2016

[2]Zhang Ying,try to analyze the fire design of large LNG LPG reception station.[J]. chemical management.2015

[3]Wang Gang Shi, the fire safety design of skid mounted LNG filling station. [J].Journal of Armed Police Academy. 2014 (12)

[4] Zheng Shunrong. Analysis of the design points for fire protection design of LNG/L-CNG gas filling station.[J]. standards and quality of China Petroleum and chemical industry. 2014 (11)

[5]Guo Haitao.LNG terminal station integrity system construction points.[J].equipment management and maintenance.2017 (02)

[6]Lin Jianbin,Hu Chao.LNG receiving terminal ship unloading operation risk analysis and Countermeasures .[J]. safety, health and environment. 2017 (06) 